Agárdi, Izabella. "Intersections of Memory and History in Rural Hungarian Women's Life Narratives: Three Case Studies." Hungarian Cultural Studies. e-Journal of the American Hungarian Educators Association, Volume 14 (2021): http://ahea.pitt.edu DOI: 10.5195/ahea.2021.428

\title{
Intersections of Memory and History in Rural Hungarian Women's Life Narratives: Three Case Studies
}

\section{Izabella Agárdi}

\begin{abstract}
The article contextualizes the oral life stories of three Hungarian-speaking women and their connections to the national histories of East-Central Europe. Through these three life narratives, I argue that in reconstructing their own life stories, the women articulate historical change. The women - born in the 1920s in the aftermath of the AustroHungarian Empire and coming of age in a socialist Eastern bloc as citizens of different nation-states - make up a generation as well as a mnemonic community with divergent versions of their community's past. They talk about childhood in the interwar era, their maturation during the Second World War, their married life and work during the early years of socialism and their retirement years after 1989. In so doing, they give shape to starkly different family histories and personal experiences which inform not only their political sensibilities, but also their sense of womanhood, ethnicity, social standing and assessments of the past. While placing themselves into a sequence of events, they maintain their sense of integrity and construct political subjectivities. Their stories are imprints of a deeply divided collective memory of a generation bearing all the complexities that make women's history different from the mainstream historiographical canon.
\end{abstract}

Keywords: rural women, oral history, gendered memory, trauma, nostalgia, twentieth century in East-Central Europe

Biography: Izabella Agárdi is a permanent fellow at the Institute of Advanced Studies, Köszeg, and a lecturer at the University of Pannonia. She holds a PhD from Utrecht University, The Netherlands, an MA in Gender Studies from Central European University and an MA in English Studies from the University of Szeged, Hungary. Her research interests are oral history, gender studies, rural women's history, contemporary historiography, and literary theory. She focuses on the intersections of personal and public narratives, practices of periodization and tropes of narrating twentieth-century history in Central Europe. She has also published on the material culture and political rhetoric of former socialist countries. She is a former member of several European research networks of excellence, including Cliohres, Athena and ATGENDER. izabella.agardi@iask.hu

\section{Three Parallel Lives}

The present article is based on a larger book project that examines a generation of Hungarian-speaking women who were born between the two world wars in territories that had formerly been part of the Austro-Hungarian Empire, but later became newly formed nation-states. My primary interest in the book is to trace how women tell history, i.e. the ways in which they conform to or subvert conventions of interpretation when creating historical narratives that use their personal memories as points of reference. In this paper, I will concentrate on the different life 
Agárdi, Izabella. "Intersections of Memory and History in Rural Hungarian Women's Life Narratives: Three Case Studies." Hungarian Cultural Studies. e-Journal of the American Hungarian Educators Association, Volume 14 (2021): http://ahea.pitt.edu DOI: 10.5195/ahea.2021.428

trajectories that the stories express. I will trace the possibilities and limitations of establishing three women as speaking subjects on matters of their country's recent past and their assessments of successive historical periods. I dwell on the moments when women's stories either conform to or evade the extant cultural or national frameworks for narrating personal experiences. The narratives of women's lives follow a personal path and touch on larger frameworks, such as historical amnesia, learned stereotypes and marked or unmarked ethnicity. The stories reproduce staples of canonized historical discourse and also span topics from the universal to women's own personal memories. The narrators utilize distinctive storylines to formulate ideal visions of themselves, to make political arguments and reflect on macro-historical events.

The three life stories I have chosen for this article can be seen as accounts of parallel life stories, told to me in the form of life reviews. According to Thompson (2000), life reviews are oral narratives that are the products of the final stage of memory when there is a heightened desire to remember, albeit with an increased selectivity of memories. Told by narrators who have experienced retirement and/or the trauma of widowhood, the narratives are also acts of closure upon an active life. The three life reviews I analyze below are fragmented and incomplete with regards to conveying facts about the women's life events. Conforming to how individuals tell stories, the stories leap back and forth in time and the chronological linearity that is characteristic of written stories is not easy (or sometimes even impossible) to establish. However, from the fragments that we do learn, starkly different family and individual stories emerge, wrapped in gendered memories, which bear the imprint of vast historical changes and lingering past legacies. As good storytellers, all three women are uninhibited in ways of self-expression. Their stories came about amidst lively conversations as we sat in their kitchens or living rooms. Paula Horváth tells me a life story that is much less about her life events than about her political arguments, aiming to legitimize the interwar period and discredit four long decades of state socialism. Magdolna Ács, a woman of mixed ethnic origins, creates a fascinating life story in which she argues for her own historical agency by way of conforming to the Hungarian majority both internally and externally. Finally, Eszter Szabó, a descendant of an artisan Hungarian family in Vojvodina, tells a life story defined by ethnic difference and the unceasing trauma of genocide.

As ethnic tensions in East-Central Europe and the West Balkans have gradually increased in the past few years, these life stories gain increased importance for younger generations. They are not to be seen simply as personal testimonies, but also as interpretations of history that carry a variety of perspectives defined by gendered experiences, ethnicity and changing ideals of national belonging. The three case studies show that personal oral narratives allow us to see conceptual connections that individual women make between their experiences and the collective fate of their immediate community. They also reveal possible explanatory frames and their attached emotive content (blaming, anger, self-victimization, and lament) and women's relationship to national history. The quite ordinary lives of these three women represent only a select few among many of their contemporaries whose personal recollections bear lingering legacies that political ruination has successfully kept alive. These legacies have been passed on and are very much present in the collective imaginary of Hungarians at home and abroad, even long after the Second World War, the Cold War, the 1989 democratic transition and two decades after the millennium. 
Agárdi, Izabella. "Intersections of Memory and History in Rural Hungarian Women's Life Narratives: Three Case Studies." Hungarian Cultural Studies. e-Journal of the American Hungarian Educators Association, Volume 14 (2021): http://ahea.pitt.edu DOI: 10.5195/ahea.2021.428

\section{The Idolized Genteel Womanhood and Polarized History in Paula Horváth' Memories}

Paula was born in 1927 in Pécs, of a mother of Austrian and a father of Turkish origin, a rare mixed ethnic background at the time. Paula's father was a first-generation migrant who worked as a civil servant, converted to Catholicism and did not keep to Turkish traditions. An only child, Paula spent her childhood in relative security and happiness. She recalls that her mother was a fashionable, soft-spoken lady who often dressed in long, heavily draped dresses. Paula's childhood memories were fragmented records of a long-gone era that has receded into the dim and faded black-and-white photo-images of the interwar period, images that we may have seen in old photographs or newspapers. Svetlana Boym (1995) draws an important distinction between restorative and reconstructive nostalgia in which the former produces a simplified, idolized view of the past and the later produces a critical, sometimes even contradictory memory of the past. As Paula was telling me about her carefree childhood and how she was "bathed in milk and honey" [tejbe' vajba' fürösztöttek], her restorative nostalgia recalled the idyllic image of childhood: a place and time of no return. She recalled a distant world that was brutally ended by the Second World War and the subsequent political systems.

Childhood stories speak of parents, grandparents, ancestors (i.e., personal origin), siblings, cousins and childhood friends, who fill the anecdotes with characters. On a collective level, even though irredentism, political Catholicism and re-constructing the national-territorial-cultural unity of Hungarians were on the agenda of high politics, families often lived a reality far away from these official discourses. The themes that emerge in individual memories of the period are predominantly those of poverty, social inequality, play, mischief, labor and respect for authority. However, Paula's account of her childhood memories differs from this scheme. By detaching her personal experiences from her general memories, or rather assessments, of the historical period, she remembers a society within which hierarchy and inequality were accepted by all and social order was only threatened by those who were themselves the embodiments of social ills:

Now I am talking about the times before the war and I can only say that those who, for example, used to come to us, the laundry woman or the woman who did the ironing, it was not bad for them! They also had their nice little, decent, clean szoba-konyha ['one-room apartment with kitchen'] like poorer folks, the locomotive engineers, conductors and postmen, but they also had it good! I never heard anybody complain. Well, of course, the poorer people might have had less on the table, but everybody could get enough to eat...they could also educate their children, they could provide the family with good food, they could dress nicely, for instance, before the war these working women also had straw hats and silk dresses. So it was not bad!

[Na most én a háború elötti időkröl beszélek, azt tudom mondani, hogy például aki mihozzánk járt mosnónö, vagy vasalónö, nem volt nekik rossz! Azoknak is megvolt a szép, rendes, kis tiszta szobakonyhás lakásuk, akkor ilyen szegényebbek, mint mozdonyvezető, kalauz, postás, de azoknak se volt rossz! Én nem hallottam, hogy valaha valaki panaszkodott volna. Jó, a szegényebbeknek hát talán kevesebb jutott az asztalra, de jól lakott mindenki...az is tudta a gyerekét taníttatni, tudta jó étellel, itallal ellátni a családot, szépen öltözködtek, például a háború elött ezeknek a munkásasszonyoknak is nyáron kis szalmakalap volt és selyemruha. Szóval nem volt rossz.] (All translations done by the author, I.A.) 
Agárdi, Izabella. "Intersections of Memory and History in Rural Hungarian Women's Life Narratives: Three Case Studies." Hungarian Cultural Studies. e-Journal of the American Hungarian Educators Association, Volume 14 (2021): http://ahea.pitt.edu DOI: 10.5195/ahea.2021.428

Paula has very few memories of her own experiences and instead dwells on the general historical context. Unlike many others of her age, she does not insist upon elaborating with small personal anecdotes about her particular experiences. Although we do not learn much about the little girl, we do get an assessment of the historical era. Paula's memories of childhood provide one of a variety of viewpoints on the interwar period, which seem to reproduce the static, generic image of vertically steep, hierarchical social and gender relations. Paula's rather polemical account corroborates with other women's memories, which highlight and take part in reproducing the contestations of politicized memory of the Horthy era. Paula's contemporaries I have interviewed frequently employ the theme of social hierarchy and emphasize unequal landed property relations pointing to the prevalence of large estates and the local influence of estate holders. Generally, the social immobility and stagnation contained in women's memories provide a basis to argue for or against the legitimacy of the regime of the period. That legitimacy, however, is always measured and negotiated alongside a critical glance at socialism.

Instead of sharing the details of her school days or wartime memories, Paula decides to leap forward a decade and extensively describe the memory of a single, significant incident that occurred in the dark days of collectivization under the new socialist regime. One morning in 1950, Paula's husband was taken away by the ÁVÓ ['Hungarian Secret Police']. It was a traumatic event that left a pocket of silence throughout their subsequent lives. The husband was away for six weeks while the family was left behind to wonder what had happened to him. Paula was in her twenties and had a two-year-old daughter to take care of. The story opens with the common opening phrase of deportation narratives, "they rang the doorbell":

One early morning they rang the doorbell in July of ' 50 . They came from the secret police [saying] that 'they have to search the house.' One didn't ask too many questions at that time. And they searched everywhere all through the apartment, but they didn't find anything that they, let's say, didn't like. And then they called in [to the headquarters]...and then the secret police took my husband away and up to this day we don't know why, only that he was taken up to Budapest, to 60 Andrássy [the headquarters of the Hungarian Secret Police] and there he was detained for six weeks, and as they took him away without a word, they let him go without a word, too.... We don't know why he was taken away. We don't know, we have no idea, they didn't say anything, but those six weeks were a horror for us.... And then he returned after six weeks, my mother died two months after that, and then nothing remarkable happened.

[Még '50 júliusában egyszer hajnalban csöngettek, az ÁVÓ-tól jöttek, hogy nálunk házkutatást köll tartani. Ugye az ember nem sokat kérdezhetött abba' az idöbe'. És akkor össze-vissza kutattak a lakásba' mindent, de semmi olyat nem találtak, ami nekik mondjuk nem tetszett. S akkor betelefonáltak... hogy nem találtak semmit, ,,behozzuk?” És valószínü azt mondta, hogy igen, és akkor az én férjemet elvitte az ÁVÓ, azt sem tudjuk a mai napig, hogy minek, csak azt tudjuk, hogy fölvitték Pestre az Andrássy út 60-ba és ott volt 6 hétig vizsgálati fogságban, és ahogy szó nélkül elvitték, szó nélkül haza is engedték. Mai napig nem tudjuk, hogy mér' vitték el. Nem tudjuk, fogalmunk nincs, ök nem mondtak semmit, csak hát azér' borzalom volt az a 6 hét, nekünk... És akkor visszajött, 6 hét után, anyukám rá két hónapra meghalt, és aztán utána olyan emlitésre méltó nem történt már.]

This story is emblematic of the Rákosi regime and its coercive practices. József Saád, who collected stories of deportations that took place in the Hortobágy and Nagykunság regions (mid-Eastern part of Hungary, the Plains) in Hungary between June 23, 1950 and March 31, 1953 , (2004) argues that personal stories of early socialism construct a genre in themselves. 
Agárdi, Izabella. "Intersections of Memory and History in Rural Hungarian Women's Life Narratives: Three Case Studies." Hungarian Cultural Studies. e-Journal of the American Hungarian Educators Association, Volume 14 (2021): http://ahea.pitt.edu DOI: 10.5195/ahea.2021.428

According to Saád, most narratives follow a so-called deportálás sablon ['deportation pattern'] that is characteristic of the early fifties despite the fact that each and every narrative (re)constructs an event unique to the particular narrator.

Paula's story is not only a story of deportation, but also an incomplete, gap-filled story relaying a prosthetic memory of her husband's temporary detainment at the infamous address of 60 Andrassy Avenue. First the headquarters of the fascist Arrow Cross Party during World War II, then the seat for the Hungarian Secret Police after the communist takeover, the building at 60 Andrássy Avenue was known as a space of horror and mystery for decades (regarding the symbolic meanings attached to this building, see Lene 2009). The husband never talked about the incident after his return while Paula, who recounts the memory fifty-five years later, is the person who was left guessing what might have happened. The fact that she narrates the unknown imbues the story with a specific perspective and strategy. Paula's story could perhaps be best described as an elliptical narrative: a story that is almost "empty" of content, therefore the audience, and even the storyteller, Paula, must resort to collective memory, family anecdotes and available general historical information to fill in the missing pieces.

Paula's apolitical attitude to her trauma draws attention to her specific position in reference to the politics of memory. She does attempt to interpret her unique experience in relation to those of others, as a collective phenomenon. However, by rejecting the significance of restitution, she conveys distance from any politicized sense of doing justice. Her disillusionment with politics and the issue of human and civil rights is rather common, though not universal, among this cohort of women. As Paula puts it "now so many years have passed that one is almost not even interested" [má' annyi év elmúlott, hogy má' szinte az embert má' nem is érdekli]. For her, there is no reparation for past ills, memory is not reliable, and the articulation of memories is handicapped. Her apparent loss of interest in recounting details about her life and the adverse effects of state socialism can of course be attributed to four decades of systemic, i.e. state-imposed, silence which the 1989 political changes could not fully alter. Ágnes Losonczi (2005) writes that, after the 1989 political transitions, there was a "sudden upsurge of longstanding 'hibernated' memory." Losonczi's observations have proven true in several cases, as we probably would not know about the many silenced narratives. There are important narratives that still demand integration into both the national canon of history writing and Hungarian collective memory, such as Holocaust memories, the unchanging persecution of the Roma, instances of political violence and collective guilt and narratives of the mass rape of women in 1944-45 in Central Europe. Paula's narrative of trauma, however, is an example of the limits of articulating past events (in her case, falling victim to communist crimes) in an organized and coherent narrative form.

The four decades of family life and work experience during state socialism do not get much mention in Paula's life story. Paula claims that after the secret police incident, so traumatic at the time, "nothing worth mentioning happened" [aztán már emlitésre méltó nem történt] to the family. By playing down the significance of the subsequent fifty years, she conveyed that normalcy (or perhaps normalcy during socialism) was not a worthy subject of history. Omitting much of the next half century is surprising in another respect, namely that women's work figured as the greatest achievement of socialism towards women's emancipation. As many have argued before, by the inclusion of women in the workforce after 1950, women became full participants in the national transformation of industry. Research has already shown that women viewed such opportunities in an extremely varied way and had different motivations to work (on women's 
Agárdi, Izabella. "Intersections of Memory and History in Rural Hungarian Women's Life Narratives: Three Case Studies." Hungarian Cultural Studies. e-Journal of the American Hungarian Educators Association, Volume 14 (2021): http://ahea.pitt.edu DOI: 10.5195/ahea.2021.428

labor force participation see for example, Völgyes and Völgyes 1977; Verdery 1994 or Van der Graaf 1996).

Although my findings corroborate the extant literature on the socialist project of women's emancipation through labor, I find the fact remarkable that no real consistency can be shown between work and the narrative construction of social subjecthood and agency by women who actually worked during the socialist era (for Hungary see Fodor 2003; for Romania see Massino 2009; for Croatia see Sutlović 2019, and for Serbia see Duhaček 2015). Paula said that, for a long time, taking a job seemed unacceptable to her, so she stayed home to raise her daughter. When she finally entered the workforce in 1964 as a technical assistant at the bus company Volán, she just wanted to fulfill the minimum requirement (of ten years) for attaining a retirement pension. Her husband was the chief accountant at the same firm, which provided the family with financial security and as a decent standard of living. Paula recounts that she experienced her entry into the registered workforce as a serious trauma, convinced that women's public employment was meaningless and did not comprise much of a social use: "My soul hurt that I had to close the door and go somewhere where they did not even benefit from me! I didn't think what I did there was useful. It did no good either to my body or to my soul" [Fájt a lelkem, hogy nekem be kell most zárni a lakást, és el kell menni oda, ahol nekem nem is veszik hasznomat! Én azt nem tartottam egy haszonnak, amit én ott csináltam. Se testemnek, se lelkemnek nem esett jól].

It can be said that Paula did not buy into the ideal of the emancipated socialist working woman. According to her, the "greatest flaw of communism was that... women were forced to work" [a kommunizmus legnagyobb hibája az volt, hogy... a nöket rákényszerítette, hogy dolgozzanak]. She thinks of socialism as an evil for of mass manipulation that misled women and denies the agency of women while blaming the kommunisták ['communists'] for having a negative influence on them. The image of the misled, enslaved, morally and intellectually degraded socialist woman is an expression of absolute resistance to the image of the liberated and happy woman worker featured in the public propaganda rhetoric of the time. Paula's antifeminism rings similar to ideas that were competing with the propaganda of the emancipated socialist woman. Ideologues advocating an "anti-politics discourse" maintained that work and the public sphere made women sexually too liberal, even aggressive (see for example, Goven 2002). In Paula's similar understanding, instead of empowering a woman, the workplace degraded her both morally and intellectually, as "it is what turned women into whores" $[e z$ csinált kurvát a nökböl]. Work "did not make her smarter! Nothing was there but gossip" [Hát ott nem okosodott! Ott nem ment más, mint a pletyka!]. Such resistance finds its legitimacy in Paula's argument for the genteel womanhood of the interwar era, recalling and celebrating an ideal that prevailed among the upper classes and held that the woman's domain was the home, where she acted in service of her parents, husband and children. Paula's world was in total negation with socialism: "I say I experienced it as a tragedy. Because I grew up into a world where she [the woman] educates the children at home, she does the housework, serves her husband dinner, lunch and breakfast, and it was strange to me that now we should leave our homes" [Hát, én tragédiaként éltem meg. Azér' ugye mer' én abba' nevelödtem ugye az otthon neveli a gyereket, végzi a házimunkát, az urát vacsorával, ebéddel, reggelivel kiszolgálja, és nekem ez furcsa volt, hogy most hazulról elmegyünk]. After fulfilling the eligibility requirements for her pension, she expressed contentment with retiring once again into the safe haven of her home. After the 1989 political change, she and her husband moved to Szeged as retired pensioners. 
Agárdi, Izabella. "Intersections of Memory and History in Rural Hungarian Women's Life Narratives: Three Case Studies." Hungarian Cultural Studies. e-Journal of the American Hungarian Educators Association, Volume 14 (2021): http://ahea.pitt.edu DOI: 10.5195/ahea.2021.428

Within the context of the life story as a whole, Paula's nostalgia for the Horthy period gains an increased significance. The sharp contrast between life before and after communism appears to be a deeper organizing principle of her narrative, one that helps her argue for a time and place when (and where) she felt at home and a valued member of her family. Paula's restorative nostalgia is a device which allows her to make a political argument for the values and legitimacy of the interwar period. Paula's happy childhood during the Horthy era appears as a fantasy in which nice clothes, good food and the parent's beauty and intelligence are all necessary elements. By collapsing her personal experience of childhood and expanding it to collective experience, Paula's narration of the era ends up being generic and polemical: "He who says that it was bad in the Horthy era was either drunk or lies. It was not bad! It was not bad!... That is what I can say but I am telling you I can only praise the era before the war" [Aki azt mondja, hogy rossz volt a Horthy idöben, az vagy részeges volt, vagy hazudik. Nem volt rossz! Nem volt rossz!... Ennyit tudok angyalom mondani, de mondom, én föleg a háború elötti idöt, azt én csak dicsérni tudom]. Paula's uncritical view of the interwar period and her dismissal of the post-war era create static images of two anachronistic eras accompanied by the complete absence of the horrors of the Second World War. Although this polarized account helped Paula formulate her political views, its contrasting logic unfortunately rendered the process of historical change unaccounted for while many of her personal life events remained untold.

\section{Magdolna Ács: Assimilation to the Majority in the Life Story of a Roma Woman}

Magdolna's life story is the most unique of the three women, as she tells and evaluates periods of her life and the larger historical contexts through the lens of a racialized concept of ethnicity. Her account is premised on an argument that she managed to assimilate successfully into mainstream society. Her life narrative, in which race/ethnicity appears as a major component of subjectivity, is constructed around expressions of moral decency and social usefulness. Her life story, the visualization of ethnic difference and its erasure for her because she was fair-skinned (in her words, even "whiter" than many in the majority society) provides grounds for her symbolic assimilation into the Hungarian ethnic majority. The fact that her father was a musician appears as a crucial factor in the family's orientation towards keeping Roma traditions. Magdolna says that, even in her old age, she has her granddaughter listen to Gypsy music.

Magdolna sets up the dichotomy of "us" and "them" when speaking about the ethnic differences in her family and village community. She is a Hungarian citizen, grew up in Hungary, her native language is Hungarian and she does not speak any other languages or dialects of Romany. Still, she says of herself: "I am a Gypsy to the blood," [vérig cigány vagyok] thereby attributing this identity not to her race, but rather to the culture and traditions she socialized into. Although she prioritizes her Gypsy heritage, she was actually born into an ethnically mixed family in 1934. Henceforth I will use the term "Gypsy" as well to follow Magdolna's usage since she does not refer to herself using the term of Roma. Her mother was tót ['Slovak'], her father cigány ['Gypsy']. Interestingly, she distinctly emphasizes that her maternal grandmother was "Hungarian." Before speaking about any life events, however, she "defines" her place in society as a Romany who was accepted, even beloved by Hungarians, thus framing her subsequent story: "So, but...Hungarians...I had so many girlfriends, Hungarians, they often came over. They loved us a lot, my mother was as clean as a glass, honorable" [Úgyhogy, de ... magyarok ... annyi barátnöm vót magyarok, ük jártak hozzánk. Nagyon szerettek, anyám nagyon tiszta vót, mint a pohár, böcsületösek]. She connects physical cleanliness, moral virtues and middle-class values, which are in turn validated by the acceptance of the Hungarians. By insisting that, despite the family's 
Agárdi, Izabella. "Intersections of Memory and History in Rural Hungarian Women's Life Narratives: Three Case Studies." Hungarian Cultural Studies. e-Journal of the American Hungarian Educators Association, Volume 14 (2021): http://ahea.pitt.edu DOI: 10.5195/ahea.2021.428

poverty, her mother was always "clean as a glass" [tiszta, mint a pohár], Magdolna invalidates any sense of either her mother's or her own ethnic inferiority. Her discursive visualization of ethnic difference remains significant throughout the narrative, underlined by anecdotes, such as the one about passing for a fair-skinned Hungarian:

As you turn left on Kinizsi Street [in the town of Makó], I brought milk from there, they didn't have children at all, but there too, that lady loved me so much! 'Don't tell me you're a Gypsy girl, you're not a Gypsy girl, you don't look like one!' Well, my mother kept us clean, she was very clean, my mom! And after the war it was a world full of lice, everybody had lice, not only Gypsies, but Hungarians, too! Everybody! My mother checked my head all the time, because I had this long hair!... She checked my head every morning, so that I wouldn't have lice, but she never found any.

[A Kinizsi utcán ahogy elfordulsz balra, onnan hordtam a tejet, azoknak se vót egy szál gyerökük, de ott is úgy szeretött az a nö engömet te! Aszongya, 'Ne mondd hogy cigány lány vagy, te nem vagy cigány lány, nem úgy nézöl ki.' Hát tisztán járatott anyám bennünket, nagyon tiszta vót anya! És a háború után olyan tetves világ vót fiam, mindönki tetves vót, nem csak cigány, magyar is! Mindönki! Anyám átnézte a fejem mindig, mer' ilyen nagy hajam vót!... Mindön röggel mögnézte a fejemet, hogy nehogy tetves lögyek, de én sose, nem tanált nálam tetüt.]

In another anecdote told in connection with the 1944 Soviet invasion, Magdolna conforms to the general discourse of the time, representing the invading Soviet troops as "oriental hordes" (Peto" 2018: 58). Soviet soldiers appear in this story as the uncivilized, barbaric enemy who pollutes with lice and dirt. She talks of how "mangy" and "filthy" Russian soldiers were [rühesek vótak az oroszok, retkösek te!'] and blames them for bringing lice and skin diseases. She relates how soldiers went into the family's yard and washed themselves in the water meant for the animals to drink. The image of the Russian soldier stands in sharp contrast with the figure of Magdolna's father, who played the cello in a Roma band, earned well and was a sophisticated and elegantly dressed musician always clothed in a black, tuxedo jacket and patent leather shoes. Magdolna formulates a mini anecdote about how her father was deported "to a labor camp in the spring of ' 44 , like the Jews" [ '44 tavaszán elvitték a munkatáborba' üket is, mint a zsidókat]. In the anecdote, she emphasizes that even as he was being taken away, he was in his elegant, stage attire. Magdolna does not ponder why her father was deported in his elegant clothes; nor does she recall stories about her father's experiences in the concentration camp except when mentioning that because he was a musician, he was in a more privileged position than the other prisoners. She expresses his loss of dignity in a simple statement: "And so I say to you, it took no more than a week for their shiny shoes to fall in tatters from their feet" [S kérlek szépen, egy hét se köllött, a lakkcipö mind leszakadt a lábukrul].

Although Magdolna's father came back, after the war the family became even more declassé than before. Jobs were not available for Gypsy musicians, not even at the agricultural collectives. The persistence of antigypsy sentiments, which took effect in the Roma politics of early communist regimes, has been extensively discussed by scholars (see for example Bársony 2008: 222-256). Feitl and Sághy (Feitl 2008: 257-272; Sághy 2008: 273-308) argue that after the Second World War, until 1959 policies as well as social practices of segregation and public humiliation resulted in the systematic discrimination of the Gypsy population. Ideas for their assimilation into the Hungarian mainstream society started to be formed from 1959 onwards. 
Agárdi, Izabella. "Intersections of Memory and History in Rural Hungarian Women's Life Narratives: Three Case Studies." Hungarian Cultural Studies. e-Journal of the American Hungarian Educators Association, Volume 14 (2021): http://ahea.pitt.edu DOI: 10.5195/ahea.2021.428

Saying that in the Rákosi era (1949-53) "the communists hated the Gypsies" [a kommunisták gyülölték a cigányokat], Magdolna hints that ethnic discrimination was systemic. In the early years of communism, racism took the form of not providing the Roma with job opportunities. Magdolna laments that her father lost his job at a restaurant and later, when she got married, neither she nor her husband were able to find employment. Magdolna only validates ethnic discrimination when speaking of the Rákosi era. Later, during the "the Kádár regime" which lasted from 1957 to 1989, at least her husband was able to find employment thanks to connections.

They did not employ us because we were Gypsies. The kulaks said, 'We don't need them as they did not bring anything into the collectives, and we brought horses, cows, and ploughs, machines'.... But then my husband's childhood friend gradually became a Party Secretary and my husband says to him, 'Don't mess with us, Sanyi, take us!' He says, 'Alright, there will be a meeting this week, I'll mention you'... it was the Kádár regime then. And he brought up the topic [at one of the party meetings] and came to us on his bike saying happily, 'Come they've taken you', three people from the band. Not us women! God damn that Méhedszki, or Barát [Party Secretary]!

[Nem vöttek föl bennünket, me' cigányok vótunk. A kulákok azt mondták, hogy 'ide nem köllenek, me' nem hoztak be semmit se, nem hoznak be a TSZ-be. Mink mög behoztuk a lovat, tehenet, mög, ekéket, gépeket!'... Na majd az uramnak a barátja, a gyerökkori barátja lassan párttitkár lött. Oszt akkor, mondta neki az uram, „Hát ne toljatok mán ki velünk Sanyi, hát vögyetök mán föl! Aszongya, „Jó van”, aszongya, „,most közgyülés lösz a hétön, oszt ott akkor majd fölemlitelek bennetöket... má' akkor a Kádár rendszer vót. És akkor fölhozta, oszt gyütt nagy örömmel hozzánk biciklivel, hogy „,na gyertök, fölvöttek tiktöket!" három személyt a zenekarbul. Nem minket asszonyokat! Fene az anyját annak a Méhedszkinek, vagy Barát.]

Magdolna worked nine years without being officially employed. In the mid-1960s, she finally got a proper job at a shoe co-op where she worked until her retirement in the late 1980s. When asked about the best period of her life Magdolna points to the "Kádár era" because it was then that "everybody could work" [mindönki dógozhatott]. She speaks highly of Kádár's state socialist regime and, as a counterpoint to Paula's dismissive opinion, Magdolna's nostalgia is saturated with vehement emotions and reasoning connected to the socialist leader. She concludes that in 1989 she "wept when our father, Kádár, died” [én ríttam, mikor Kádár apánk möghalt].

\section{Eszter Szabó: Silenced History and Lingering Trauma in the Life of a Hungarian Woman from Vojvodina}

Similar to Paula's, Eszter's story comprises a single-event life review premised upon the emphasis of communist crimes. In contrast to Paula, Eszter builds her narrative around her disadvantaged position as an ethnic Hungarian and the trauma of losing her father to brutal acts of ethnic cleansing during the winter of 1944. The narrative can be read both as a testament to the missing memory of Hungarians in Vojvodina and as a generic East-Central European narrative bearing the difficult legacy of the Second World War and persisting anti-Semitism. Born in 1929, Eszter grew up in "Old Yugo" and she remembers having had a happy childhood, together with her parents and older brother. Her mother was a seamstress while her father 
Agárdi, Izabella. "Intersections of Memory and History in Rural Hungarian Women's Life Narratives: Three Case Studies." Hungarian Cultural Studies. e-Journal of the American Hungarian Educators Association, Volume 14 (2021): http://ahea.pitt.edu DOI: 10.5195/ahea.2021.428

worked in a beer warehouse and kept bees on the side. In Eszter's childhood memories, the four of them did not have too many hardships, other than the fact that as ethnic Hungarians they lived in relative poverty. In her story, Eszter gives a description of an ethnic division of land and property relations in Vojvodina. With its interpretation of the interwar period in Old Yugoslavia along lines of ethnic difference, her account is not exceptional. However, in forming this elaborate narrative of continuity in ethnic difference and turning it into "history-as-ethnic disadvantage" based on land ownership, Eszter's account is quite unique. She goes back a thousand years to Hungary's first king to explain why Germans in her childhood were wealthier than Hungarians and she finds the origin of Serbs' wealth in Trianon and the post-war land distributions and re-settlements.

And generally, it was like that in each village, it is so even today, that the Hungarians were poorer, they were the poorest among all the ethnicities.... Because when in the First World War, when it ended, you know and the Monarchy lost, unfortunately the Hungarians paid the greatest price.... Yugoslavs got this territory and the big powers founded Yugoslavia. Unfortunately, those who got the land still rule. These dobrovojaces [settlers in Vojvodina after the First World War] got rights to settle and they got the best lands! Now, and, what you may know better than I do, is that the Germans were also settled here earlier, King Stephen brought them here with special... privileges. Craftsmen and such, they taught these nomad and pagan folks, we Hungarians. And they came from somewhere they settled in Hungary, and they got privileges. Right? The Serbs too. And the Germans. We, poor Hungarians, had what we had. That was ours...the thinnest lands.

[És általába úgy volt, minden községbe, most is, az újba, hogy a magyarok, azok szegényebbek vótak, azok vótak a nemzetiségek között a legszegényebbek... Mert amikor... elsö világháborúba... ugye, vége volt, itt osztrák-magyar monarchia veszített, ugye. Sajnos a magyarok fizettek rá a legjobban... ugye a területet, ezt megkapták a jugoszlávok, ugye Jugoszláviát alkottak a nagyhatalmak, sajnos, akik most is uralkodnak, és akkor kaptak födet. Ezek a dobrovojacok kaptak letelepedést, és a legjobb födeket kapták. A legjobb födeket kapták. Na, viszont, azt meg tudod talán, jobban, mind én, hogy a németek meg azé, mer azok is betelepítettek voltak valamikor, már István király ugye hozta különleges izével, na... jutalommal... és azok is kiváltságot kaptak. Igaz? A szerbek is. A németek is. Mink szegény magyarok, ami volt, amit birtunk, az volt a mienk, a legsoványabb födek. ]

In Eszter's story social relations are endowed with the dimension of ethnicity. Traditionally, the amount of land owned was an important marker of social standing amongst agricultural rural populations. Eszter's understanding and formulation of social inequality through the unfair distribution of land is by no means surprising as it belongs to a more common understanding of wealth and value in rural agricultural regions (on rural women's memories about land in the Romanian context see Anghel and Dobay 2019a and 2019b). Eszter speaks of a carefree childhood when her family shared a good, friendly rapport with the Serbs in the village. Her recollection of her childhood sound as though those years were generally defined by ethnic inequality, even though her family's situation, as she recounts, was not much affected by inequalities connected to land ownership. Eszter attended the first four grades in the Hungarian elementary school and two more in the Serbian school. In her memories, this was a period of peaceful coexistence of different ethnic groups and multilingualism was the general norm in her 
Agárdi, Izabella. "Intersections of Memory and History in Rural Hungarian Women's Life Narratives: Three Case Studies." Hungarian Cultural Studies. e-Journal of the American Hungarian Educators Association, Volume 14 (2021): http://ahea.pitt.edu DOI: 10.5195/ahea.2021.428

village. However, relations that were peaceful before the war deteriorated starkly after the 1941 Hungarian take-over of Vojvodina: tensions and armed conflicts lead to an irresolvable condition of disadvantage for ethnic Hungarians in the region.

In the spring of 1941, Eszter was still a schoolgirl when Hungarian army units reoccupied northern parts of Yugoslavia. She remembers waiting for the soldiers to arrive, and then eventually missing their welcome because she overslept. From this point onwards, her story turns grim as she recounts some of the subsequent murders and planned actions of sabotage committed by Tito's partisans against Hungarian occupying forces. After 1941, she recounts, her school days were filled with worries about village friends and family members. In the winter of 19441945 tragedy struck with the loss of her father in the massacre committed in Eszter's village, Zsablya.

The massacre at Zsablya forms the ultimate rupture in Eszter's life narrative. From written accounts, we know that the mass killings were in retaliation for the 1942 "Bloodshed of Novi Sad" committed by Hungarian forces who mainly targeted the Serb and the Jewish civil population, killing approximately 3,800 people in the smaller villages and the larger towns located in the region of Bácska [Serb. 'Bačka']. During the four-day operation hundreds of Russians and Hungarians also fell victim to the executions. The bloodshed became a symbol for war crimes committed in other re-annexed territories. ${ }^{1}$ The $1944-45$ retaliation by the Tito-led partisans was a series of brutal acts of collective punishment against ethnic Hungarians, killing thousands of civilian residents, the details of which are still unknown (for historical accounts see Sajti A. 2004; Mészáros 2012). Eszter's story of the incident reads as follows:

I was so scared, my Lord! I'm sure she [Eszter's childhood friend] was scared too as we were walking...it was getting dark and as we were approaching the curve in the road, I could see the Calvary and the stations from far away. And on one side of the stations there were these mass graves. And as we got closer, we saw something black. What can it be? A big dog or what? We kept going, we were lethargic as we went, then as we got closer, we looked inside. And it was black soil. It was dug up till here and it was black soil - just left like that, and they threw them in. There were two of them: my father and another man. And they threw some soil over them and left the rest. We don't know but I tell my mother, come look.... When I look closer, it's a piece of brain! Whom might it have belonged to -the dogs didn't touch it, I don't think - either to my father or to that other man, a Hungarian man. But there and then I saw a.... Hungarian brain! It was trampled on. It was January and [the ground] was frosty, snowy, there were these short bushes and grass, and they were all downtrodden with big boots, and there was blood and stuff around. So, I saw this, too.

[De féltem, Istenem! Ő is félt, biztos, mer megyünk-megyünk, jó esteledett mán, majdnemhogy a kanyarig, de még nem, de közel van a... és nézem messzirü, hogy... lássuk ottan a kálváriát, ahogy a stációk vannak, hogy a stáció egyik oldalán vótak ezek a tömegsirok, és ahogy megyünk messzirü, lássuk, hogy jaj, mi van ott, feketedik. Jaj, ott valami nagy kutya van, vagy mi lehet az? De csak megyünk... olyan fäsultan mentünk, oda megyünk, közelítünk, hát... odamentünk, és belenéztünk. És

\footnotetext{
${ }^{1}$ The story of the Novi Sad bloodshed became widely known through Tibor Cseres' 1964 novel, Hideg napok
} ['Cold Days'], and the movie by the same title, directed by András Kovács. 
Agárdi, Izabella. "Intersections of Memory and History in Rural Hungarian Women's Life Narratives: Three Case Studies." Hungarian Cultural Studies. e-Journal of the American Hungarian Educators Association, Volume 14 (2021): http://ahea.pitt.edu DOI: 10.5195/ahea.2021.428

fekete föld volt. Olyan, mint hogy ha egy ... igy, ennyi... ennyi volt kiásva, és fekete föld volt... vagy fekete föld volt még több, és beledobálták... Ketten voltak, édesapám, meg még egy ember. Oszt aztán valamennyi földet dobtak, és ott hagyták a többit... mondom anyámnak, hogy jaj, nézd csak! Mikor én nézek, egy agyvelö! Na most, hogy kié volt az, egy héttel elöbb, nem-e bántották a kutyák, nem hiszem. Vagy az emberé, vagy az én édesapámé, vagy melyik emberé, magyar emberé, de ott egy ... egy magyar agyvelöt láttam. És összetaposva, olyan, ez... januárba volt, és olyan fagyos... fagyos, havas, mittudomén, fü volt, olyan alacsony bokrok, és azok mind olyan nagy bakancsokkal össze vótak ott taposva, és vót ott vér, meg mi minden. Hát ezt is láttam.]

After the massacre, Zsablya was one of three settlements where Hungarians were not allowed to return. Eszter spent a year and a half in an internment camp, where she was often assigned to clean toilets. After her internment ended, she settled in Ada with her family. As her plans to study evaporated, she remembers having gone to work at a canned food factory, where she met her husband, Béla, a divorced man with two children. Béla, a war veteran who was deeply shaken by his experiences on the eastern front, was eleven years her senior and the two of them, in his words, were two broken souls making a life together. Eszter repeatedly lamented that she never got over the fact that her father's body was not found, and it was not possible to declare him dead and bury him according to local customs. She carried this pain throughout the rest of her life. During the 1990s, historical research started to expose the details of both the 1942 and the 1944-45 incidents, but the Serbian government did not officially acknowledge these events or issue an apology until 2013, which Eszter unfortunately did not live to see.

Eszter's memories of socialism are scanty and sporadic. She emphasizes her apolitical nonconformism by saying she declined Party membership, even though it meant a sub-standard salary at the time. In the 1980s, the canned-food factory in which she worked went bankrupt and consequently she chose to retire. Her retirement story is both a story of corruption and criticism of the Yugoslav economic model, within which Eszter tells the story of Yugoslavia's uniquely independent market socialist economy and its system of self-management albeit from a specific perspective (for an analysis of Yugoslavia's economic system see for example, Dubey 1975; Flaherty 1978, 1982). In the story anti-Semitism and corruption jointly inform Eszter's interpretation of socialism's demise. Her story reads as follows:

Well, the factory dissolved, the work stopped and...these communist managers let it go bankrupt. They stole as much as they could. It was not so much about the theft, but inadequate investment. They took on so much credit and loans that their interest suffocated us. And they would go abroad on big trips. They held feasts. In London. And it came out that there were these tester-machines...they weren't sold anywhere yet. [And] some Jewish company... guaranteed that...what we produce, will have a market: dried goods and what not, canned fruits and the like, and there was the foreign trade manager, or whatever, our production manager, in London. And the Jewish traders are sneaky because the retailer of the machine was Jewish, and he was connected to the other one, who was supposed to buy the dried goods. So, [he said], 'It will be a smashing thing here, big investment, construction and production and the money will be flowing in, thousands of workers.' Nothing came out of it! Then we heard, it leaked out that...those traders were skillfully entertaining the guests. They flew to Paris from London. In the Moulin Rouge in each box...the dancer woman descended from a helicopter.

[No, a gyár megszünt, megszünt dógozni, és mittudomén .. ezek a kommunista vezetök csödbe vitték. Loptak, ahogy csak bírtak azok is. Nem is a lopás, hanem a helytelen beruházás. Olyan nagy 
Agárdi, Izabella. "Intersections of Memory and History in Rural Hungarian Women's Life Narratives: Three Case Studies." Hungarian Cultural Studies. e-Journal of the American Hungarian Educators Association, Volume 14 (2021): http://ahea.pitt.edu DOI: 10.5195/ahea.2021.428

krediteket vettek... kölcsönöket vettek föl, hogy a kamatja le...lefojtott bennünket, és mentek külföldre nagy utakat, dáridókat csináltak. Londonba vettek [gépeket]. És kitünt, hogy próbagépek azok, nem is ... még sehun nem vót az eladva, csak ez elsőnek valamelyik mittudomén, zsidó cég... mer' garantálták, hogy még el is lesz... meg is lesz véve a kész, amit földolgozunk, szárított dolgok, meg mittudomén, kompótok, ez-az-amaz, minden, és ott volt a külkereskedelmi igazgató, a mi igazgatónk, ott volt Londonba. És a huncutok, ugye, zsidó kereskedők, mert mondom az eladó, a gép eladója is zsidó volt, meg aki ugyanahhoz csatlakozva majd átveszi, kereskedö, átveszi a szárított árut. Úgyhogy mondta, 'bomba izé lesz itten, nagy beruházás, építkezés, és termelés, és pénz folyik majd be, munkások ezrei. ' Nem lett belöle semmi. Aztán hallottuk, aztán szivárgott ki az, hogy a ... azok persze mind ügyesen, fogták a vendégeket... vendégösködtek... átrepültek Párizsba. Ott a Moulin Rougeba', ott... aztán mesélték, hogy mindegyiknek a páholyába ... a helikopterbü' ereszkedett a táncosnö.]

In Eszter's story, the Jewish businessmen cheated their communist partners by selling them a tester machine and then not providing a market for their products. Moreover, they morally corrupted the factory's "communist managers" by hiring dancers to entertain them in the Moulin Rouge. This image of the post-war, "sneaky Jewish trader" is quite the opposite of the fair and generous Jewish merchant of prewar childhood memories. In Eszter's story, thus, Jewish traders appear as illustrations of how all Jews are deceitful, unethical and bring economic decay. Through employing the "trope of corruption," as defined by Akhil Gupta (Gupta 1995: 375-402) Eszter finds a way to address the crisis of economy, politics and governance which took place in socialist Yugoslavia and eventually contributed to its collapse.

Like the stories of many of her generation, Eszter's story of life and trade in Tito's Yugoslavia has strong anti-Semitic overtones. While her contemporaries often speak of "Jewish communists," Eszter equates Jewishness with capitalism. Either communist or capitalist, in women's post-war stories the figure of "the Jew" emerges as one allied with the enemy. The two constructions of the Jewish "Other" reflect the Cold War binary, which was built on the concept of the bipolar world-system. Personal accounts like Eszter's are abundant with simplistic binaries, making it clear that it is impossible to account for memories of socialism without consulting the lingering legacies of the Second World War and the subsequent Cold War. It is clear from Eszter's narrative that the marker of "Jewish," has become an empty signifier that now rarely stands for real embodied, flesh-and-blood subjects, but for some vague idea of the enemy that pollutes, as Ferenc Erös so aptly argued (Erös 2005; Erös 1996: 71-78). It may stand for the opposing radical poles of American and Russian hegemony and their imperialisms Such stereotypical figurations are informative of the extent to which personal memories in EastCentral European countries carry the imprints of discourses, the products of political periods and the regimes that consolidated their legitimacy on the "ruins" of the Second World War (see Benjamin 1998: 132-154).

\section{Conclusion}

Whether belonging to the majority or ethnic minority, for many Hungarian families the disillusionment accompanying the loss of the Second World War, the reestablishment of the Trianon borders, the forced population exchanges and deportations after the 1947 Paris Treaty, incidents of collective punishment in the surrounding reconstructing people's republics and the Soviet occupation only exacerbated tensions that became frozen into the political unit(y) of the 
Agárdi, Izabella. "Intersections of Memory and History in Rural Hungarian Women's Life Narratives: Three Case Studies." Hungarian Cultural Studies. e-Journal of the American Hungarian Educators Association, Volume 14 (2021): http://ahea.pitt.edu DOI: 10.5195/ahea.2021.428

Soviet bloc. Although Yugoslavia was expelled from the bloc, ethnic tensions were stifled in silence by means of a powerful, state rhetoric of egalitarianism. In Hungary and elsewhere, tensions that lingered after the war were easily revived in the late 1980s with the emergence of ethno-nationalisms.

However "messy" or fragmented, the stories of individual women are just as much the products as the indicators of unresolved tensions. Hurt, trauma, guilt, shame and oppression continue to linger in women's memory narratives. Stories like those of Paula, Magdolna or Eszter can only be understood by considering that politicized gender, ethnic and class differences are formative elements of female subjectivities and hence of their accounts of history. Eszter's universalizing and self-victimizing tone of "poor Hungarians," her vilification of Serbian characters, her persistent anti-Semitism, or Magdolna's racialized views of the Roma are all building blocks of minority narratives that have their counterparts in the context of other ethnic groups. Paula's anti-feminist polemic and polarized views of political regimes are also alive and thriving throughout the societies of East-Central Europe. The three case studies show that personal oral narratives are excellent sources through which historians may gain a deeper understanding of the intricate conceptual connections that women make among their own and collective experiences, their explanatory frames and their attached emotive content. Such mechanisms of personal recollection bear the lingering legacies that both state socialist and democratic political regimes have kept alive and, thus, inform our current political, social, cultural and knowledge systems (on the appropriation of material and immaterial heritage of the purged other see Yashin 2009: 7). Consequently, these legacies of a painful, unresolved recent past still shape the collective memory of Hungarians at home and abroad, even long after the Second World War, the Cold War and the collapse of socialist regimes.

\section{Works Cited}

Anghel, Iulia, Dobay, Krisztina Melinda. 2019a. "Gender Identities in Rural Romania. Part I: Women's Places and the village Within the City." Cogito: Multidisciplinary Research Journal, 11:1: 117-130.

Anghel, Iulia, Dobay, Krisztina Melinda. 2019b. "Gender Identities in Rural Romania. Part II: Women Passing their Legacy." Cogito: Multidisciplinary Research Journal, 11:3: 71-87.

Benjamin, Walter. 1998. "Critique of Violence." One-way Street and Other Writings. London: Verso: 132-154.

Boym, Svetlana. 1995. "From the Russian Soul to Post-Communist Nostalgia." Representations, 49: 133-166.

Duhaček, Daša. 2015. "Gender Equality in Serbia. "A Drop of Oil” in the Waters of Inequality?" Gender (In)equality and Gender Politics in Southeastern Europe: A Question of Justice. Ed. Christine M. Hassenstab and Sabrina P. Ramet, Palgrave Macmillan, 2015: 108-125.

Dubey, Vinod. 1975. Yugoslavia: Development with Decentralization, Baltimore: The Johns Hopkins P.

Erős Ferenc. 1996. "Gyermekíjjesztő dajkamese a vér, a vád. Adalékok a vérvád pszichológiájához." ['Scary Children's Stories, the Blood, the Blame: Additions to the Psychology of Blaming'] Vérvádak üzenete. Budapest: Minoritás Alapítvány: 71-78. 
Agárdi, Izabella. "Intersections of Memory and History in Rural Hungarian Women's Life Narratives: Three Case Studies." Hungarian Cultural Studies. e-Journal of the American Hungarian Educators Association, Volume 14 (2021): http://ahea.pitt.edu DOI: 10.5195/ahea.2021.428

Erös Ferenc. 2005. “Az előítélet-kutatás dilemmái” ['The Dilemmas of Research on Prejudice’]. Kisebbségek kisebbsége. A magyarországi cigányok emberi és politikai jogai, ['The Minority of Minorities: The Human ad Political Rights of Hungarian Roma'] Eds. Mária Neményi and Júlia Szalai. Budapest: ÚMK.

Feitl, István. 2008. "A cigányság ügye a napirendről lekerült. Előterjesztés az MDP Politikai Bizottsága számára 1956 áprilisából”. ['The Case of the Roma Was Removed the Table: Initiative to the Political Committee of HDP from April 1956'] Múltunk 1: 257-272.

Flaherty, Diane. 1982. "Economic Reform and Foreign Trade in Yugoslavia." Cambridge Journal of Economics. 6: 2: 105-142.

Flaherty, Diane. 1978. "Self-Management and Requirements for Social Property: Lessons from Yugoslavia". http://www.nodo50.org/cubasigloXXI/congreso/flaherty_15abr03.pdf

Fodor, Éva. 2003. Working Difference, Women's Working Lives in Hungary and Austria 19451995. Durham and London: Duke UP.

Goven, Joanna. 2002. The Gendered Foundations of Hungarian Socialism: State, Society, and the Anti-Politics of Anti-Feminism. 1948-1990. Berkeley: UCP.

Lene, Otto. 2009. "Post-Communist Museums: Terrorspaces and Traumascapes" The Power of the Object. Museums and World War II. Ed. Esben Kjeldbaek, Edinburgh: Museums: 324360.

Losonczi, Ágnes. 2005. Sorsba fordult történelem. ['History Turned Destiny’] Budapest: Holnap.

Massino, Jill. 2009. "Constructing the Socialist Worker: Gender, Identity and Work under State Socialism in Braşov, Romania." Apasia, 3: 131-160.

Mészáros, Zoltán. 2012. "Az 1944-45-ös események minősítései." [“Assessments of the 1944-45 Events.'] Létünk, 1:31-45.

Petö, Andrea. 2018. Elmondani az elmondhatatlant. A nemi eröszak története Magyarországon a II. világháború alatt. ['Speaking the Unspeakable: The History of Rape in Hungary During the Second World War'] Budapest: Jaffa.

Saád, József. 2004. “Telepessors.” ['Settler Fate’] Ed. Saád József, Budapest: Gondolat. http://www.telepesek.hu/aktual/telepessors.htm

Sághy, Erna. 2008. "Cigánypolitika Magyarországon az 1950-es-1960-as években.” ['Roma Politics in Hungary in the 1950s-1960s'] Múltunk 1: 273-308.

Sajti A., Enikő. 2004. Impériumváltások, revízió, kisebbség. Magyarok a Délvidéken 1918.1947. ['Changing Empires, Retaliations, Minorities: Hungarians in the Vojvodina'] Budapest: Napvilág.

Sutlović, Leda. 2019. “'Let's Preserve the Achieved: And Ask for More!' Transformations of Gender Politics in Croatia." Women's Studies International Forum, 77: 1-8.

Thompson, Paul. 2000. The Voice of the Past, Oral History. Oxford and New York: Oxford UP. Van der Graaf, Mary. 1996. Everything and Nothing Changed. Gender Relations in Hungarian Agriculture During the Transition. Wageningen: Department of Gender Studies in Agriculture, Wageningen UP.

Völgyes, István, Völgyes, Nancy. 1977. The Liberated Female: Life, Work, and Sex in Socialist Hungary. Boulder, CO: Colorado UP.

Yashin, Yael Navaro. 2009. "Affective Spaces, Melancholic Objects: Ruination and the Production of Anthropological Knowledge." Journal of the Royal Anthropological Institute (N.S.), 15:1: 1-18. 